\title{
The impact of human capital development on the economic and social development of a country: empirical study
}

\author{
Jel̦ena Lonska, Iveta Mietule \\ Rezeknes Augstskola, Faculty of Economics and Management
}

\begin{abstract}
Methodologically this research is based on the approach of many social scientists who argue that there is a bidirectional link: one runs from human capital development to economic growth and overall human development, when human capital helps increase national income and society development; the other runs from economic growth to human capital development, as the resources from national income are allocated to activities contributing to human capital development. The study aims to empirically verify the existence of this interaction by carrying out a correlation analysis of the human capital development level among 120 countries, assessed by the Human Capital Index, and the world's national economic development level, as demonstrated by the Global Competitiveness Index, as well as the level of development of the world's nations (societies) as demonstrated by the Human Development Index.

The result of the analysis empirically demonstrated a strong link between the human capital development with the country's economic $(r=+0.944, p=0.000)$ and national development $(r=+0.882, p=0.000)$ in total by all countries. Nevertheless, carrying out the correlation analysis by groups of countries, which are divided according to the calculation methodology of the Global Competitiveness Index, depending on their stage of economic development, the relationship between human capital development and nation's development is becoming weaker in some groups of countries, with the remaining strong correlation between the development of human capital and the economic development of a state in all groups of countries. This means that only highly developed human capital can contribute to the country's economic development, and vice versa, national economic performance increases human capital development in the framework of effective development policy. On the other hand, not always a close interaction between nation's development and human capital development can be faced, since a highly developed human capital means the quality of the developed human capital.
\end{abstract}

Keywords: economic growth, global competitiveness index, human capital, human capital index, human development index.

\section{INTRODUCTION}

Human capital is a set of person's abilities and skills, having direct impact on one's economic and social activity potential. The definitions of human capital usually emphasise the individual's education, skills, abilities and knowledge that increase the productivity of his economic activity, however, the content of the concept is much broader. Human capital includes both technical and social skills. The concept of "human resources" is also widely exploited, and refers to the number and the proportion of working age people in the society [1].

The main difference between the concept of "human capital" and the concept of "human resources" is investing in a factor. Human capital can be interpreted as an economic concept if investments into human resources, including employees, are made, i.e., contribution of financial resources, which is an individual, business or government expenditure with the aim to increase the capital. Investments in human capital are today's targeted expenditure to ensure additional income in the future [2].

The concept of human capital is primarily related to the economic behaviour of individuals, especially in the way in which their accumulated knowledge and skills boost their productivity and income, thereby increasing the productivity and income of the society on the whole. By purposefully contributing its efforts and means into education and skills, the society can achieve the desired economic return - both at the individual and society levels. On the other hand, many human capital components not only enhance the efficiency of individual economic activity, but also influence one's personal and social well-being $[1,3]$.

Investments in human resources and human capital are becoming a key factor for the development of a company, branch and country as a whole $[3,4]$.

The first economist who articulated the idea that population with its productive capacity is the nation's wealth was William Petty [5]. 
Under the conditions of the scientific and technological revolution taking place in the 50ies of the twentieth century, the world was struck by the deficit of highly qualified staff, with thereby growing educational qualification when much attention was devoted to the level of peoples' attained education. Therefore, beginning with the 60ies of the twentieth century, special attention was granted to the quality of the labour force, namely to the level of education and professional training in particular. The human capital theory emerged within this period, embracing people's knowledge, skills and abilities, as well as other people's qualities that provide individual economic and social benefits. The development of the concept of human capital is associated with T. Schultz $[6,7,8$, 9], G. Becker [10, 11], B. Weisbrod [12], G. Mincer [13], W.L. Hansen [14], M. Blaug [15], R. Layard [16], and other authors' works.

Contemporary foundations of the human capital theory were established and defined in the works of famous American economists T. Schultz $[6,7,8,9]$ and G. Becker [11]. T. Schultz in his theory justified economic efficacy of public expenditure on inhabitants' education, medical care, vocational training, i.e. financial expenditure on education is modified resulting from such human intellect and culture development, which in its own way is a form of fixed remuneration and profit for both a person and society as a whole. The more qualified people's work is, the higher is their capital and, consequently, the yield on capital (labour income). Human capital is viewed as one of the most significant factors of economic growth and the growth of economic potential $[6,7,8,9]$.

Becker, performing the subsequent development of The human capital theory, concluded that the investment in human capital can bring the highest degree of income to the national economy, thus stimulating its growth. These investments also determine the need for new knowledge, innovation boosting the field of technology and contribute to the overall development of a country [10,11].

It should be noted that the human capital theory sees people as a key factor in the economic growth of territories. In the XXI century an individual and his/her potential has become a vital driving force for the economy and hence territorial development. Thus, all investments in a person, his/her intelligence and health become in advance beneficial for the society and the country as a whole. Accordingly, the investment in culture, education, spiritual sphere is to be seen as a highly economically effective investment in human capital. In developed countries, investment in human capital is becoming the underlying fundamental for the territorial competitiveness and economic growth. Human capital is a foremost, crucial national wealth re-growth factor. Human resources have become a key factor in achieving competitive advantage in today's economy [17].
The value of human capital is also analysed in the R. Florida's Creative Class theory, which is grounded on economic and regional development and its facilitation instruments. Florida's theoretical conclusions are based on three key development factors, the so-called 3T - Technology, Talent and Tolerance. If a company / city / region / territory has all these $3 \mathrm{~T}$, it is able to attract creative workforce with the ability to innovate and contribute to economic growth. According to the Creative Class theory, the class of creative people under the conditions of modern economy is vital for the economic growth of a region. Knowledge as a source of wealth creation and economic growth has replaced the efficiency of natural resources and physical labour. Today, talent has become the main factor of production, and the competitive advantages are inherent to those areas which are able to create, maintain and attract the best human capital $[18,19]$.

The present study aims to empirically demonstrate human capital development link with the country's economic development (in this study - the country's competitiveness) and the overall development of society (in this study - nation's development).

\section{MATERIALS AND METHODS}

The empiric study of the authors, presented in this article, is secondary and is based on three global comparative researches: Human Capital Report of the World Economic Forum [20], Human Development Report of the United Nations Development Programme [21] and Global Competitiveness Report of the World Economic Forum [22].

Human Capital Index (HCI) is a new measure for capturing and tracking the state of human capital development around the world, and it was first calculated in 2013. The index is based on 4 pillars, containing a total of 51 indicators: 3 core determinants of human capital - education (12) ${ }^{1}$, health (14) and employment (16), plus those factors that allow these three core determinants to be translated into greater return - enabling environment (9). Each pillar's significance weight is 0.25 of the total index value. When calculating the indicator values, the data are standardised employing z-score statistics as standard deviations from a mean, therefore, the total value of the index may also be negative [20].

Human Development Index (HDI) has been used since 1990 and it was the first attempt to incorporate different aspects of quality of life. It was modified and redefined in 2010. This composite index aggregates 3 dimensions: a long and healthy life, measured by life expectancy at birth; access to knowledge, combining mean and expected years of schooling; a decent standard of living, measured by Gross National

${ }^{1}$ The number of indicators in each pillar is indicated in brackets 
Income per capita (PPP US\$). Higher value means better well-being for nations. The values of the index vary in a range from 0 to 1 , where 1 is the highest level of human development in a country [21].

Since 2005, the World Economic Forum has based its competitiveness analysis on the Global Competitiveness Index (GCI), a comprehensive tool that measures the micro- and macroeconomic foundations of national competitiveness. GCI involves static and dynamic components as a weighted average of many different aspects. GCI is based on 12 pillars, which contain 114 indicators: institutions (21), infrastructure (9), macroeconomic environment (5), health and primary education (10), higher education and training (8), goods market efficiency (5), labour market efficacy (10), financial market development (8), technological readiness (7), market size (4), business sophistication (9) and innovation (7). A nation's level of competitiveness reflects the extent to which it is able to provide rising prosperity to its citizens and GCI has examined various factors enabling national economies to achieve sustained economic growth and long-term prosperity. The value of the index is measured in a scale from 1 to 7 , where 7 is the maximum value, namely, it indicates the highest level of competitiveness [22].

In the course of the present empirical study the authors worked with HCI values referring to 2013 (HCI 2013), HDI values for the year 2013 (HDI 2013) and GCI values for the period 2014-2015 (GCI 20142015). In overall, 120 world's countries were analysed, which have all three index values. For the detailed research of interrelation of human capital (HCI) and the country's economic development (GCI) and the nation's development (HDI), the correlation analysis of a total of 120 group of countries was conducted in the SPSS programme, as well as performed separately in each of the five groups of countries in which they are divided according to their GCI stage of development: according to the GCI calculation methodology, various world's countries appear to be in five stages of economic development, depending on their level of GDP per capita and competitiveness of individual growth factors:

1) Stage 1: factor-driven economies,

2) Transition from stage 1 to stage 2 economies,

3) Stage 2: efficiency-driven economies,

4) Transition from stage 2 to stage 3 economies,

5) Stage 3: innovation-driven economies [22].

\section{RESULTS AND DISCUSSION}

The conducted correlation analysis of the countries' HCI 2013, HDI 2013 and GCI 2014-2015 shows that (see Table 1):

1) in all 120 group of countries there is a strong positive statistically significant correlation between both HCI 2013 and GCI 2014-2015, where $r=+0.944$, $\mathrm{p}=0.000$, as well as between HCI 2013 and HDI 2013 , where $r=+0.882, p=0.000$. This means that among the state human capital development and national competitiveness as well as nation's development there is a close relationship observed, which is manifested as follows: when the value of human capital in a country increases, the economic return on human capital also grows, promoting the competitiveness of the country, the nation's development also increases together with the development of human capital. In its turn, the improvement of national economic indicators (in this study - competitiveness) and the increase in nation's development, in the framework of qualitative development policy, also leaves a positive effect on the development of human capital, since there is a bidirectional link connecting these phenomena;

2) a strong positive statistically significant correlation is observed among the HCI 2013 and GCI 2014-2015 in all five groups of countries of national economic development stages: stage 1 group of countries $r=+0.897, p=0.000$; transition from stage 1 to stage 2 group of countries $r=+0.751, p=0.000$; stage 2 group of countries $r=+0.812, p=0.000$; the transition from stage 2 to stage 3 group of countries $r$ $=+0.815, \mathrm{p}=0.000$; stage 3 group of countries $\mathrm{p}=$ $+0.932, \mathrm{p}=0.000$, which certainly confirms the theoretical assumptions on the fact that exactly the developed human capital is a successful driving force of the economic development, and vice versa, since the countries with high economic performance are interested in the development of their own human capital, implementing the country's overall development policies aimed at the country's main resource, i.e. enhancement and growth of the human capital;

3) a strong positive statistically significant correlation is observed between the HCI 2013 and HDI 2013 in the economic development of stage 1 group of countries $r=+0.709, p=0.000$ and stage 3 group of countries $r=+0.752, p=0.000$. This is justified by the fact that the stage 1 group of countries according to the GCI calculation methodology includes countries with low GDP per capita, where there is mostly unskilled labour and low productivity, and which specialise in the extraction of natural resources, hence the low HDI values result from low $\mathrm{HCI}$ values, and vice versa. Stage 3 group of countries according to the GCI calculation methodology includes countries with a high GDP per capita, where there is skilled labour and which compete by producing goods using the most sophisticated production processes and by innovating the new ones, therefore these countries have a highly developed human capital (high HCI), which also contributes to the overall nation's development (high HDI) and vice versa; 
CORRELATIVE INTERRELATION AMONG HCI 2013, GCI 2014-2015AND HDI 2013 ACROSS ALL COUNTRIES AS A WHOLE (N $=120)$ AND IN THE BREAKDOWN OF GROUP OF COUNTRIES OF GCI ECONOMIC DEVELOPMENT STAGE, PEARSON CORRELATION COEFFICIENTS

\begin{tabular}{|c|c|c|c|c|}
\hline & & & $\begin{array}{l}\text { GCI } \\
2014-2015\end{array}$ & $\begin{array}{l}\text { HDI } \\
2013\end{array}$ \\
\hline \multirow{3}{*}{$\begin{array}{l}\text { Stage 1: Factor driven economies } \\
\text { BGD, BFA, CHM, CMR, CIV, ETH, GHA, GUI, IND, } \\
\text { KEN, KGZ, LAO, LSO, MDG, MWI, MLI, MRT, MOZ, } \\
\text { NIC, NGA, PAK, SEN, TZA, UGA, VNM, YEM }{ }^{2}\end{array}$} & \multirow{3}{*}{$\begin{array}{r}\mathrm{HCI} \\
2013\end{array}$} & $\begin{array}{l}\text { Pearson } \\
\text { Correlation }\end{array}$ &, $897^{* *}$ &, $709^{* *}$ \\
\hline & & Sig. (2-tailed) & ,000 & ,000 \\
\hline & & $\mathrm{N}$ & 26 & 26 \\
\hline \multirow{4}{*}{$\begin{array}{l}\text { Transition from stage } 1 \text { to stage } 2 \text { economies } \\
\text { DZA, AZE, BTN, BOL, BWA, HND, IRN, KWT, MDA, } \\
\text { MNG, PHL, SAU, VEN }\end{array}$} & \multirow{4}{*}{$\begin{array}{l}\text { HCI } \\
2013\end{array}$} & Pearson &, $751^{* *}$ & ,429 \\
\hline & & $\begin{array}{l}\text { Correlation } \\
\text { Sig }\end{array}$ & 003 & \\
\hline & & Sig. (2-talled) & ,003 & $\frac{143}{12}$ \\
\hline & & $\mathrm{N}$ & 13 & 13 \\
\hline \multirow{3}{*}{$\begin{array}{l}\text { Stage 2: Efficiency-driven economies } \\
\text { ALB, ARM, BGR, CHN, COL, DOM, EGY, SLV, GEO, } \\
\text { GTM, IND, JAM, JOR, MKD, MAR, NAM, PRY, PER, } \\
\text { ROM, SRB, ZAF, LKA, THA, TUN, UKR }\end{array}$} & \multirow{3}{*}{$\begin{array}{l}\text { HCI } \\
2013\end{array}$} & $\begin{array}{l}\text { Pearson } \\
\text { Correlation }\end{array}$ &, $812^{* *}$ &, $524^{* *}$ \\
\hline & & Sig. (2-tailed) & ,000 & ,007 \\
\hline & & $\mathrm{N}$ & 25 & 25 \\
\hline \multirow{3}{*}{$\begin{array}{l}\text { Transition from stage } 2 \text { to stage } 3 \text { economies } \\
\text { ARG, BHR, BRB, BRA, CHL, CRI, HRV, HUN, KAZ, } \\
\text { LVA, LBN, LTU, MYS, MUS, MEX, OMN, PAN, POL, } \\
\text { RUS, SUR, TUR, ARE, URY }\end{array}$} & \multirow{3}{*}{$\begin{array}{l}\text { HCI } \\
2013\end{array}$} & $\begin{array}{l}\text { Pearson } \\
\text { Correlation }\end{array}$ &, $815^{* *}$ &, $451^{*}$ \\
\hline & & Sig. (2-tailed) &, 000 &, 031 \\
\hline & & $\mathrm{N}$ & 23 & 23 \\
\hline \multirow{3}{*}{$\begin{array}{l}\text { Stage 3: Innovation-driven economies } \\
\text { AUS, AUT, BEL, CAN, CYP, CZE, DNK, EST, FIN, } \\
\text { FRA, DEU, GRC, ISL, IRL, ISR, ITA, JPN, KOR, LUX, } \\
\text { MLT, NLD, NZL, NOR, PRT, QAT, SGP, SVN, ESP, } \\
\text { SWE, CHE, TTO, GBR, USA }\end{array}$} & \multirow{3}{*}{$\begin{array}{r}\mathrm{HCI} \\
2013\end{array}$} & $\begin{array}{l}\text { Pearson } \\
\text { Correlation } \\
\end{array}$ &, $932^{* *}$ &, $752^{* *}$ \\
\hline & & Sig. (2-tailed) & ,000 & ,000 \\
\hline & & $\mathrm{N}$ & 33 & 33 \\
\hline \multirow{3}{*}{ All economies } & \multirow{3}{*}{$\begin{array}{l}\text { HCI } \\
2013\end{array}$} & Pearson &, $944^{* *}$ &, $882^{* *}$ \\
\hline & & Sig. (2-tailed) &, 000 & ,000 \\
\hline & & $\mathrm{N}$ & 120 & 120 \\
\hline
\end{tabular}

**. Correlation is significant at the 0.01 level (2-tailed).

*. Correlation is significant at the 0.05 level (2-tailed).

Source: compiled by the authors utilising correlation analysis of the data of [20], [21], [22].

4) in two groups of countries between the HCI 2013 and HDI 2013 a moderate positive statistically significant correlation is observed: stage 2 group of countries $r=+0.524, p=0.007$ and the transition from stage 2 to stage 3 group of countries $r=+0.451, p=$ 0.031 . According to the GCI calculation methodology these groups of countries include the countries that have a relatively high GDP per capita indicator values (for stage 2 economies: $\$ 3,000<$ GDP per capita $<\$$ 8,999 , for transition from stage 2 to stage 3 economies: \$ 9,000<GDP per capita $<17,000 \$$ ), where labour productivity, production efficiency and quality of output growth is observed, being directly dependent on the level of human capital development. The fact that this case reflects a moderate correlation is due to the fact that this group of countries includes some countries with uncharacteristic $\mathrm{HCI}$ values that do not correspond to the HCI trends of the rest of countries included in these groups of countries. For instance, at stage 2 group of countries the average $\mathrm{HCI}$ 2013 value $=-0.230$ and the average HDI 2013 value $=0.709$ (see Table 2), this group includes Paraguay with HCI $2013=-0.546$ and HDI $2013=0.676$, Dominican Republic with HCI $2013=-0.499$ and HDI $2013=0.700$, Namibia with HCI $2013=-0.534$ and HDI $2013=0.624$. Also the transition from stage 2 to stage 3 economies group with the total average HCI $2013=0.144$ and the average HDI $2013=0.785$ (see Table 2) includes some countries with uncharacteristic HCI values typical for this group of countries, for instance, Argentina with HCI $2013=-0.120$ and HDI $2013=0.808$, Lebanon with $\mathrm{HCI}=-0.220$ and HDI $=$ 0.765 , Suriname with HCI $2013=-0.420$ and HDI $2013=0.705$. As it can be seen, less developed human capital can be observed in these countries, compared with the other countries represented in the group, but it does not affect the whole level of nation's development of these countries.

${ }^{2}$ United Nations 3-letter countries codes 
5) the moderate statistically insignificant correlation $\mathrm{r}=0.429, \mathrm{p}=0.143$ is observed in the transition from stage 1 to stage 2 group of countries between HCI 2013 and HDI 2013. In this case, it is justified by the fact that exactly this group of countries primarily includes the countries with a relatively underdeveloped human capital (the average value of the HCI 2013 in this group of countries is -0.357), while the average value of the nation's development indicator in this group of countries HDI 2013 is 0.708 , which is close to the world's average HDI 2013 value 0.727 (see Table 2). For instance, Algeria HCI $2013=$ -0.954 and HDI $2013=0.717$, Kuwait HCI $2013=-$ 0.059 and HDI $2013=0.814$, Venezuela HCI $2013=-$ 0.564 and HDI $2013=0.764$

TABLE 2

THE AVERAGE VALUES OF GCI 2014-2015, HCI 2013 AND HDI 2013 ACROSS ALL COUNTRIES AS A WHOLE (N = 120) AND IN THE BREAKDOWN OF GROUP OF COUNTRIES OF GCI ECONOMIC DEVELOPMENT STAGE

\begin{tabular}{|c|c|c|c|c|}
\hline & & GCI 2014-2015 & HCI 2013 & HDI 2013 \\
\hline \multirow{3}{*}{$\begin{array}{l}\text { Stage 1: Factor } \\
\text { driven economies }\end{array}$} & Mean & 3,569 &,- 728 &, 505 \\
\hline & $\mathrm{N}$ & 26 & 26 & 26 \\
\hline & Std. Deviation &, 353 &, 326 &, 074 \\
\hline \multirow{3}{*}{$\begin{array}{l}\text { Transition from stage } \\
1 \text { to stage } 2 \\
\text { economies }\end{array}$} & Mean & 4,102 &,- 357 &, 708 \\
\hline & $\mathrm{N}$ & 13 & 13 & 13 \\
\hline & Std. Deviation & ,441 & ,293 &, 073 \\
\hline \multirow{3}{*}{$\begin{array}{l}\text { Stage 2: Efficiency- } \\
\text { driven economies }\end{array}$} & Mean & 4,146 &,- 230 &, 709 \\
\hline & $\mathrm{N}$ & 25 & 25 & 25 \\
\hline & Std. Deviation & ,301 &, 226 &, 045 \\
\hline \multirow{3}{*}{$\begin{array}{l}\text { Transition from stage } \\
2 \text { to stage } 3 \\
\text { economies }\end{array}$} & Mean & 4,380 &, 144 &, 785 \\
\hline & $\mathrm{N}$ & 23 & 23 & 23 \\
\hline & Std. Deviation &, 378 & ,260 &, 033 \\
\hline \multirow{3}{*}{$\begin{array}{l}\text { Stage 3: Innovation- } \\
\text { driven economies }\end{array}$} & Mean & 4,998 &, 788 &, 881 \\
\hline & $\mathrm{N}$ & 33 & 33 & 33 \\
\hline & Std. Deviation &, 483 & ,379 &, 035 \\
\hline \multirow{3}{*}{ All economies } & Mean & 4,295 &,- 00015 &, 727 \\
\hline & $\mathrm{N}$ & 120 & 120 & 120 \\
\hline & Std. Deviation &, 645 &, 640 &, 144 \\
\hline
\end{tabular}

Source: compiled by the authors employing mean comparison analysis of the data of [20], [21], [22].

Many researchers and scientists, when analysing human capital development and economic growth, conclude that there is a bidirectional link: one runs from economic growth to human capital, as the resources from national income are allocated to contributing activities to human capital development; the other runs from human capital to economic growth, when human capital helps increase national income $[23,24,25,26]$.

There are many studies on how the increase in the human capital development level facilitates the economic growth of a country [23, 27, 28, 29]. Certainly a well-educated and healthy human capital is a significant factor in creating the state competitive advantages, it influences the labour efficacy and productivity, which, in its turn, attracts foreign direct investment in a country, in other words, better health and education attract money to a nation's economy. An educated and healthy labour often becomes a fundamental influence factor for foreign investors when making a decision regarding the capital investment [30].

The empirical studies [31] confirm that there is a link between the development of human capital and economic growth at both micro and macro levels. At the micro-level the individual income growth is associated with advanced levels of education, which can be considered as an essential foundation for the enhancement of an individual's labour productivity and the introduction of novelty, which, in its turn, contributes to the overall competitiveness of the country. Of course, the level of people's education itself cannot achieve a significant transformation in the economy, but in a symbiosis with a sound national policy it has a major impact on domestic and foreign investments, thus imposing economic activity performance [32]. With regard to the impact of education on economic growth at the macro level, a number of empirical studies [33, 34] show the positive impact of education, but its degree varies depending on the quality of educational activities. It should be noted that it is insufficient just to educate people, there should also be the opportunity to "use" them productively. Also here, the great importance is placed on the implemented state policy in enhancing national competitiveness. The improvement of economic competitiveness requires well-educated and trained people, technological and network readiness as well as knowledge and skills to work in an innovation-rich world [34]. 


\section{CONCLUSION}

The findings of the research reflect the visible link establishing connection among the human capital development and the country's economic growth and competitiveness, as well as the development of a society (nation). Undoubtedly, only the quality resource, in this case - the developed human capital is the country's economic and nation's development basis. The authors of this article conclude that investment in human capital has two objectives: the economic objective means that the state, investing in people's development, is hoping to achieve the financial-economic return on the invested capital, hence country's competitiveness and economic growth, but the public objective means that human development is the final destination of the territorial development process, which can be achieved through the economic processes. Human capital concept allows understanding that at the early stages of the territorial development process the key role is granted to an individual, his accumulated knowledge, skills and abilities, which when skilfully exploited, ensure successful achievement of the outcome of this process. In the context of such territorial development an individual is both a "tool" and an "objective".

Nevertheless, with regard to the human capital development connection related to the development of a nation (society), it is somewhat weaker, especially in the country groups of economies at the transition stage of development (according to the methodology for calculating GCI) as human capital development is influenced by various factors, which may not be very developed, even in countries which have developed in accordance with the Human Development Index. For instance, in order to achieve a relatively high HDI value, it is necessary for people to have the longest possible life expectancy at birth, adequate human training process and the relatively large GNI per capita. In the case of HCI, it is not enough, because it takes into account not only the quantitative indicators, but also the qualitative ones, as only through qualitative analysis one can judge on the level of human capital development. Consequently, there are countries with relatively developed nations, but underdeveloped human capital. As it is revealed in Table 2, only in the transition from stage 2 to stage 3 group of countries, and innovation-driven group of countries, the average HCI 2013 value is positive, it means that in most of these countries, the human capital is "qualitatively" developed, which is logical, for these countries being in these economic development groups of countries.

The countries should implement the human capital development policies that enhance human potential and national industry opportunities, and allow the countries to avoid "commodity trap" as well as to diversify the economic activity. The enhancement of the developed human capital contributes to transformation process of "resources economy" turning into a "knowledge economy" when the quantity becomes quality and extensive economic growth - intensive. Economic growth creates the necessary fiscal space for investments in human capital as well as leads to the synergy of economic and social policies. Investment in human capital is not only the investment in improving the state of health, education and social security perfection, it is also the success basis for the dynamic and competitive global economy. In order to make efficient use of human capital, a coherent public education, labour market and social protection system should be elaborated.

\section{$\mathrm{V}$ REFERENCES}

[1] A. Zobena, „Latvija. Pārskats par tautas attīstību 2006/2007. Cilvēkkapitāls: mans zelts ir mana tauta?" Rīga: LU Sociālo un politisko pētījumu institūts, 2007.

[2] I. Mietule, "Theoretical aspects of human capital formation in the interaction between the economic and education sectors", in Proceedings of the international scientific conference, Vol.1, Personality Socialization research institute of RHEI, 2011, pp. 359-368.

[3] J. Lonska and V. Boronenko, "What is the Key Element for the Territory's State of Development?", in WASET International Conference on Environmental, Cultural, Economic and Social Sustainability (April 14-15, 2013, Venice, Italy) proceedings, Issue 76 April 2013 Venice, 2013, pp.187-192.

[4] I. Mietule, "Selected Issues of the Meaning of Human Capital in Economic Development", in Wydawnictwo Naukowe Uniwersytetu Mikolaja Kopernika, Torun, 2009, pp. 219-226.

[5] У. Петти, Экономические и статистические работы. Москва: Соцгиз, 1940.

[6] T. Schultz, "Capital formation by education", in Journal of Political Economy, 68, 1960, pp. 571-583.

[7] T. Schultz, "Investment in human capital", in American Economic Review, Vol. 51, No. 1, 1961, pp. 1-17.

[8] T. Schultz, The Economic Value of Education. New York: Columbia University Press, 1963.

[9] T. Schultz, Investment in Human Capital: The Role of Education and of Research. New York: Free Press, 1971.

[10] G. Becker, "Investments in Human Capital: A Theoretical Analysis", in The Journal of Political Economy, Vol. 70, Issue 5, Part 2, 1962, pp. 9-49.

[11] G. Becker, Human Capital: a Theoretical and Empirical Analysis, with special reference to education. National Bureau of Economic Research, New York: Columbia University Press, 1964.

[12] B. Weisbrod, External Benefits of Public Education: An Economic Analysis. Industrial Relations Section, Department of Economics, Princeton University, 1964.

[13] J. Mincer, "Investment in Human Capital and Personal Income Distribution", in Journal of Political Economy, 66/4, 1958, pp. 281-302.

[14] W. L. Hansen, "Education, Income, and Human Capital", in Income and Wealth, No. 35, New York: National Bureau of Economic Research, 1971.

[15] M. Blaug, "The Empirical Status of Human Capital Theory: A Slightly Jaundiced Survey", in Journal of Economic Literature, Vol. 14, No. 3 (Sep., 1976), 1976, pp. 827-855.

[16] R. Layard, "Human Capital and Earnings: British Evidence and a Critique", in Review of Economic Studies, Wiley Blackwell, Vol. 46 (3), 1979, pp. 485-503

[17] М. С. Хараева, "Человеческий капитал - как фактор опережающего экономического развития", in Креативная экономика, № 3 (27), 2009, pp. 20-27.

[18] R. Florida, The Rise of the Creative Class, and How It's Transforming Work, Leisure, Community and Everyday life. New York: Basic Books, 2002. 
[19] R. Florida, "Cities and the Creative Class", in Cities \& Community, 2(1), 2003, pp. 3-19.

[20] World Economic Forum, The Human Capital Report 2013.

[21] K. Malik, Human Development Report 2014. Sustaining Human Progress: Reducing Vulnerabilities and Building Resilience. United Nations Development Programme, 2014.

[22] K. Schwab and X. Sala-i-Martin, The Global Competitiveness Report 2014-2015. World Economic Forum, 2014.

[23] G. Ranis, F. Stewart and A. Ramirez, "Economic Growth and Human Development", in World Development, Vol. 28, No. 2, 2000, pp. 197-219.

[24] G. Ranis and F. Stewart, "Growth and Human Development: Comparative Latin American Experience" (Center Discussion Paper No. 826). Economic Growth Center, Yale University, 2001. [Online]. Available: http://papers.ssrn.com/sol3/papers.cfm?abstract_id=275294. [Accessed: March 10, 2015].

[25] A. Ramirez, G. Ranis, and F. Stewart, "Economic Growth and Human Development" (Working paper No.18), 1998. [Online]. Available: http://www.cs.odu.edu/ dlibug/ups/rdf/remo/qeh/qehwps/qeh wps18.pdf. [Accessed: March 10, 2015].

[26] N. Bundala, "Economic Growth and Human Development; A Link Mechanism: an Empirical Approach" (MPRA Paper47648). University Library of Munich, 2012. [Online]. Available: $\quad$ http://mpra.ub.unimuenchen.de/47648/1/MPRA_paper_47648.pdf. [Accessed: March 10, 2015].

[27] T. Suri, M. A.Boozer, G. Ranis, and F. Stewart, "Paths to Success: The Relationship between Human Development and
Economic Growth", in World Development, 39 (4), 2011, pp. 506-522.

[28] P. Streeten, "Human Development: Means and Ends", in Human Development, 84.2 (May 1994), 1994, pp. 232-237.

[29] M. Boozer, G. Ranis, F. Stewart, and T. Suri, "Paths to Success: The Relationship between Human Development and Economic Growth", (Discussion Paper No. 874). Economic Growth Center, Yale University, 2003. [Online]. Available: http://www.econ.yale.edu/growth pdf/cdp874.pdf. [Accessed: March 10, 2015].

[30] K. Malik, Human Development Report 2013. The Rise of the South: Human Progress in a Diverse World. United Nations Development Programme, 2013.

[31] D. Rodrik, A. Subramanian, and F. Trebbi, "Institutions Rule: The Primacy of Institutions over Geography and Integration in Economic Development" (NBER Working Paper 9305). The National Bureau of Economic Research, 2002. [Online]. Available: http://www.nber.org/papers/w9305. [Accessed: March 10, 2015].

[32] R. Haufler and S. Andreas, Regional Integration and the Development of Tax Systems in the European Union. Oxford: Oxford University Press, 2001.

[33] P. Romer, "Endogenous Technological Change", in Journal of Political Economy, 98 (October), 1990, X71-S102.

[34] D. Hendri, "Economic Competitiveness and Human Capital: A Nexus in Indonesian Case", 2012. [Online]. Available: https://www.academia.edu/3432769/Economic Competitivene ss_and_Human_Capital. [Accessed: March 10, 2015]. 